\title{
The Tobacco mosaic virus 126-kDa Protein Associated with Virus Replication and Movement Suppresses RNA Silencing
}

\author{
Xin Shun Ding, Jianzhong Liu, Ning-Hui Cheng, Alexey Folimonov, Yu-Ming Hou, Yiming Bao, \\ Chika Katagi, Shelly A. Carter, and Richard S. Nelson \\ Plant Biology Division, The Samuel Roberts Noble Foundation, Inc., 2510 Sam Noble Parkway, Ardmore, OK 73402, U.S.A. \\ Submitted 7 October 2003. Accepted 30 January 2004.
}

Systemic symptoms induced on Nicotiana tabacum cv. Xanthi by Tobacco mosaic virus (TMV) are modulated by one or both amino-coterminal viral 126- and 183-kDa proteins: proteins involved in virus replication and cellto-cell movement. Here we compare the systemic accumulation and gene silencing characteristics of TMV strains and mutants that express altered 126- and 183-kDa proteins and induce varying intensities of systemic symptoms on $N$. tabacum. Through grafting experiments, it was determined that $\mathrm{M}^{\mathrm{IC}} 1,3$, a mutant of the masked strain of TMV that accumulated locally and induced no systemic symptoms, moved through vascular tissue but failed to accumulate to high levels in systemic leaves. The lack of $M^{\mathrm{IC}} 1,3$ accumulation in systemic leaves was correlated with RNA silencing activity in this tissue through the appearance of virus-specific, approximately 25-nucleotide RNAs and the loss of fluorescence from leaves of transgenic plants expressing the $126-\mathrm{kDa}$ protein fused with green fluorescent protein (GFP). The ability of TMV strains and mutants altered in the $126-\mathrm{kDa}$ protein open reading frame to cause systemic symptoms was positively correlated with their ability to transiently extend expression of the 126-kDa protein:GFP fusion and transiently suppress the silencing of free GFP in transgenic $N$. $t a$ bacum and transgenic $N$. benthamiana, respectively. Suppression of GFP silencing in $N$. benthamiana occurred only where virus accumulated to high levels. Using agroinfiltration assays, it was determined that the 126-kDa protein alone could delay GFP silencing. Based on these results and the known synergies between TMV and other

Corresponding author: R. S. Nelson; Telephone: +1.580.224.6600; Fax: +1.580.224.6692; E-mail: rsnelson@ noble.org

X. S. Ding, J. Liu, and N.-H. Cheng contributed equally and should be considered co-first authors.

Current address of N.-H. Cheng: Baylor College of Medicine, Department of Pediatrics, 1100 Bates St., Houston, TX 77030, U.S.A.

Current address of A. Folimonov: University of Florida, Institute of Food and Agricultural Sciences, Citrus Research and Education Center, 700 Experiment Station Road, Lake Alfred, FL 33850, U.S.A.

Current address of Y.-M. Hou: Syngenta Biotechnology, 3045 Cornwallis Rd., Research Triangle Park, NC 27709, U.S.A.

Current address of Y. Bao: National Center for Biotechnology Information, National Institute of Health, Building 45, Room 6AS.47D-45, 45 Center Dr., MSC 6510, Bethesda, MD 20892, U.S.A.

Current address of C. Katagi: B 101, 3-1592-33, Edogawadai-higashi, Nagareyama, Chiba, 270-0111, Japan. viruses, the mechanism of suppression by the 126-kDa protein is compared with those utilized by other originally characterized suppressors of RNA silencing.

Additional keywords: suppressor, virulence.

Viruses affect plant growth and development to the greatest extent during their vascular movement and subsequent accumulation in tissue distant from the inoculation site (Hull 2001). As such, it is important to understand how viruses accumulate in these distant tissues (i.e., how viruses accumulate systemically). Recent studies have determined that eukaryotic cells utilize a sophisticated system to identify and destroy aberrant or overexpressed RNA in their cytoplasm. The RNA destruction pathway is referred to as post-transcriptional gene silencing, RNA interference, or quelling, depending on the organism under study (Zamore 2001). These pathways have common enzyme constituents, but they may not entirely overlap. All can be considered forms of RNA silencing (Baulcombe 1999). A portion of this defense pathway in plants includes silencing of RNA in systemic tissue.

RNA silencing in both plants and animals is sequence specific and proceeds through the production of small (21 to 25 nucleotides [nt]) sense and antisense RNAs (Hamilton and Baulcombe 1999; Zamore et al. 2000). RNA silencing can function in plants as a defense mechanism against virus infection (Carrington et al. 2001; Vance and Vaucheret 2001; Voinnet 2001). This defense mechanism prevents virus accumulation in systemic leaves of virus-challenged, nontransgenic plants (AlKaff et al. 1998; Covey et al. 1997; Ratcliff et al. 1997). In addition, transgenes expressing viral sequences induce silencing of the homologous challenge virus and the transgene RNA (Al-Kaff et al. 1998; Lindbo et al. 1993; Smith et al. 1994).

Many plant viruses encode proteins that defeat (suppress) RNA silencing in the infected host (Voinnet et al. 1999). The specific viral proteins that suppress RNA silencing are known for some viruses and include, among others, helper component-protease (HC-Pro) from Potato virus $Y$ (PVY), 2b from Cucumber mosaic virus (CMV), p25 from Potato virus $X$ (PVX), and 19 from Tomato bushy stunt virus (TBSV; Voinnet 2001). Many of these proteins previously were shown to be necessary for the local or phloem-dependent accumulation of the encoding viruses in their respective hosts (Bonneau et al. 1998; Cronin et al. 1995; Ding et al. 1995a; Hong et al. 1997; Scholthof et al. 1995). The functions of these proteins in virus accumulation and suppression of RNA silencing are only partially understood (Mlotshwa et al. 2002). 
Other nonstructural viral proteins or their open reading frames (ORFs) are known to affect phloem-dependent accumulation of their respective viruses (Nelson and van Bel 1998). These include the $\alpha$ a protein of Barley stripe mosaic virus, 1a and 2a proteins of Brome mosaic virus (BMV) and CMV, 129- or 186-kDa proteins of Sunn hemp mosaic virus, and 126- or 183-kDa proteins of TMV (De Jong and Ahlquist 1995; Deom et al. 1997; Lakshman and Gonsalves 1985; Nelson et al. 1993; Roossinck and Palukaitis 1990; Traynor et al. 1991; Weiland and Edwards 1994). Their ability to suppress RNA silencing is not known.

Previously, we determined the basis for different disease symptoms elicited by two strains of TMV on Nicotiana tabacum L. cv. Xanthi. The attenuated "masked" (M) strain (Holmes 1934), causes very mild chlorotic mottling on systemically infected leaves, whereas the severe U1 strain induces rugosity and a well-defined light-green, dark-green mosaic on systemically infected leaves (Shintaku et al. 1996). By analysis of infections caused by transcripts of $M$ strain mutants, it was determined that $8 \mathrm{nt}$ in the $126-\mathrm{kDa}$ protein ORF, resulting in eight amino acid differences in the $126-$ and $183-\mathrm{kDa}$ proteins between the $\mathrm{M}$ and $\mathrm{U} 1$ strains, control the symptom and phloem-dependent accumulation phenotypes (Derrick et al. 1997; Shintaku et al. 1996). One or both of the 126- and $183-\mathrm{kDa}$ proteins, and not the viral RNA, are responsible for the symptom phenotypes displayed by the viruses (Bao et al. 1996).

In this study, we investigated the ability of TMV mutants, differing in their ability to induce disease, to induce RNA silencing. Based on these results, the ability of the TMV 126$\mathrm{kDa}$ protein alone to modulate RNA silencing was studied.

\section{RESULTS}

$\mathrm{M}^{\mathrm{IC}} 1,3$ infection phenotype in $N$. tabacum and isolation of mutants that induce systemic symptoms.

$\mathrm{M}^{\mathrm{IC}} 1,3$ was synthesized through site-directed mutagenesis of a cDNA clone of the $\mathrm{M}$ strain $\left(\mathrm{M}^{\mathrm{IC}}\right)$ (Fig. 1) (Shintaku et

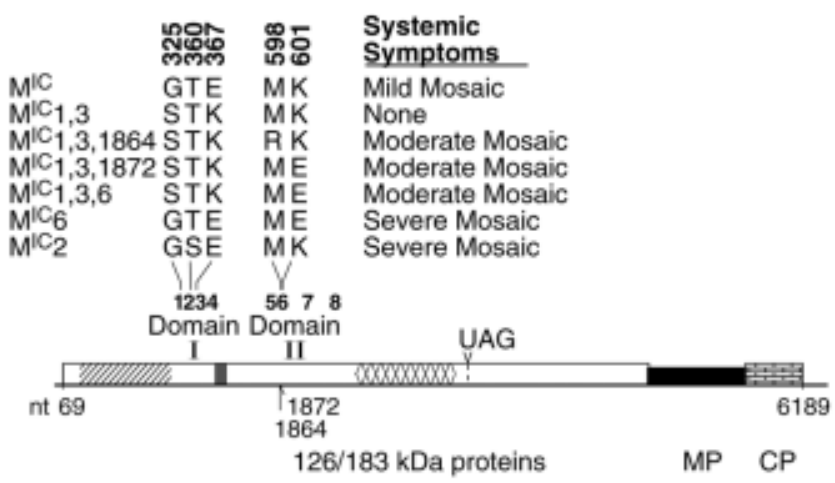

Fig. 1. Schematic of the genome organization of Tobacco mosaic virus (TMV) and protein sequence comparisons between the parental masked strain $\left(\mathrm{M}^{\mathrm{IC}}\right)$ and various mutants of this virus $\left(\mathrm{M}^{\mathrm{IC}} 1,3, \mathrm{M}^{\mathrm{IC}} 1,3,1864\right.$, $\mathrm{M}^{\mathrm{IC}} 1,3,1872, \mathrm{M}^{\mathrm{IC}} 1,3,6, \mathrm{M}^{\mathrm{IC}} 6$, and $\mathrm{M}^{\mathrm{IC}} 2$ ). Open reading frames are indicated by bars. Untranslated regions are denoted as lines. UAG designates the leaky amber termination codon. Single-hatched area = methyltransferase $(\mathrm{MT})$ domain. Cross-hatched area $=$ helicase domain. Dark gray area $=$ a region of conservation between sindbis-like plant viruses with unknown function. Domains I and II are regions with less sequence similarity between sindbis-like plant viruses and previously unknown functions (Shintaku et al. 1996). Numbers 1 to 8 indicate the positions of the 8 amino acids in the $126-\mathrm{kDa}$ protein that differ between the attenuated $\mathrm{M}^{\mathrm{IC}}$ and severe U1 strains of TMV. Amino acid sequence differences among $\mathrm{M}^{\mathrm{IC}}, \mathrm{M}^{\mathrm{IC}} 1,3, \mathrm{M}^{\mathrm{IC}} 1,3,1864, \mathrm{M}^{\mathrm{IC}} 1,3,1872, \mathrm{M}^{\mathrm{IC}} 1,3,6, \mathrm{M}^{\mathrm{IC}} 6$, and $\mathrm{M}^{\mathrm{IC}} 2$ are shown along with the amino acid location where they differ (numbers turned $90^{\circ}$ ). $\mathrm{MP}=$ movement protein, $\mathrm{CP}=$ coat protein. al. 1996). $\mathrm{M}^{\mathrm{IC}} 1,3$ infects inoculated leaves but does not induce symptoms on upper uninoculated (systemic) leaves of N. tabacum cv. Xanthi (Shintaku et al. 1996). Studies were initiated to determine the accumulation of $\mathrm{M}^{\mathrm{IC}} 1,3$ in inoculated and systemically infected leaves of this host. Although the virus accumulated in inoculated leaves at reduced levels compared with the $\mathrm{M}^{\mathrm{IC}}$ and $\mathrm{U} 1$ strains of TMV (Fig. 2), it did accumulate in vascular cells of inoculated leaves at the time when systemic symptoms normally appeared (Table 1). In addition, necrotic lesion diameters were identical for $\mathrm{M}^{\mathrm{IC}} 1,3$ and $\mathrm{M}^{\mathrm{IC}}$ on inoculated leaves of $N$. tabacum cv. Xanthi NN, a hypersensitive host for TMV. In spite of the ability of $\mathrm{M}^{\mathrm{IC}} 1,3$ to move cell to cell, systemic accumulation of $\mathrm{M}^{\mathrm{IC}} 1,3$ coat protein (CP), 126-kDa protein, and infectious virus was, at a minimum, greatly delayed compared with the other TMV strains (Fig. 2, later results, and data not shown). In addition, TMV movement protein (MP) expressed in transgenic N.tabacum cv. Xanthi did not complement MP expressed during infection to allow greater systemic accumulation of $\mathrm{M}^{\mathrm{IC}} 1,3$ (data not shown).

During the analysis of $\mathrm{M}^{\mathrm{IC}} 1,3$ accumulation in $N$. tabacum cv. Xanthi, a minority of the plants displayed chlorotic symptoms on systemic leaves more than 3 weeks postinoculation (data not shown). Tissue was harvested from systemic leaves exhibiting chlorotic mottling and virus was isolated from this tissue. cDNA from the TMV genome isolated from one plant was sequenced through all ORFs. A single substitution from the parental $\mathrm{M}^{\mathrm{IC}} 1,3$ strain was identified at nucleotide 1,864 in the 126-kDa protein ORF (position noted in Fig. 1). The altered sequence encodes an arginine in place of methionine at residue 598. This amino acid is not present in the U1 strain sequence. cDNA from a TMV genome isolated from a second plant was sequenced between nucleotides 1,022 and

\section{DPI 5 DPI \\ Inoculated leaves

Mock U1 $M^{I C} M^{I C} 1,3$ Mock U1 $M^{I C} M^{I C} C_{1,3}$

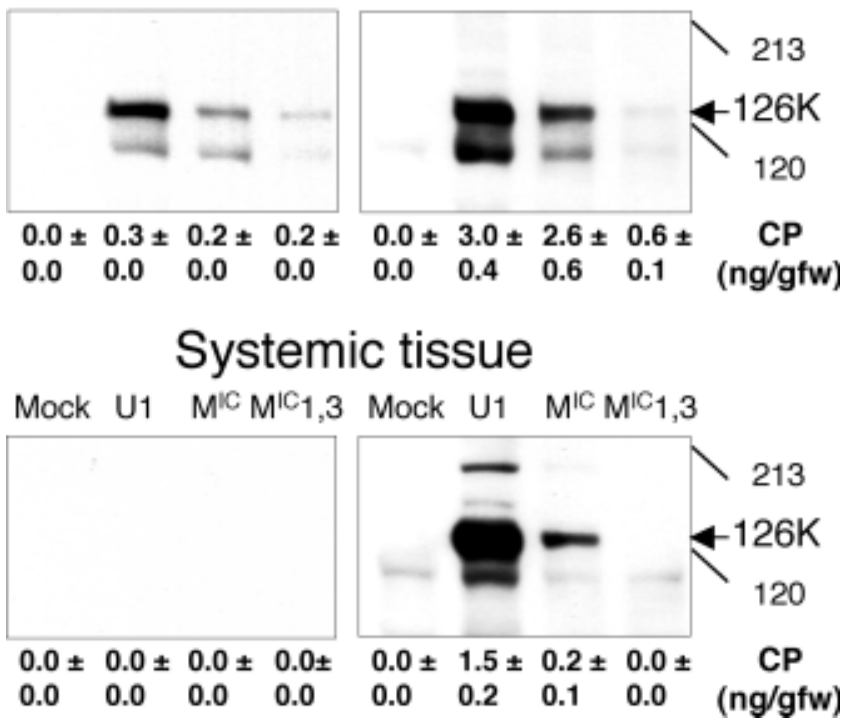

Fig. 2. Accumulation of $126-\mathrm{kDa}$ protein and coat protein $(\mathrm{CP})$ from Tobacco mosaic virus (TMV) strains and mutants in inoculated and systemic leaves of Nicotiana tabacum cv. Xanthi. Two plants were inoculated with each TMV strain or mutant $\left(\mathrm{U} 1, \mathrm{M}^{\mathrm{IC}}\right.$, and $\left.\mathrm{M}^{\mathrm{IC}} 1,3\right)$ and accumulation of viral proteins determined by immunoblot analysis (126-kDa protein) or enzyme-linked immunosorbent assay (CP) using antibodies against the respective proteins. Positions of size markers for the immunoblot analysis are shown. CP accumulation values (ng/gram of fresh weight [gfw]) are means \pm standard errors of the mean. 
2,428 , the region controlling symptom and systemic accumulation phenotypes in the mild and severe TMV strains (Fig. 1) (Derrick et al. 1997). A single substitution was identified at position 1,872, altering this nucleotide to that of the U1 strain (position noted in Fig. 1). This mutation resulted in a glutamic acid for lysine substitution at residue 601 of the $126-\mathrm{kDa}$ protein and a virus identical in sequence within this region to $\mathrm{M}^{\mathrm{IC}} 1,3,6$, a mutant virus previously described (Shintaku et al. 1996) (Fig. 1). Thus, both newly characterized viruses, referred to as $\mathrm{M}^{\mathrm{IC}} 1,3,1864$ and $\mathrm{M}^{\mathrm{IC}} 1,3,1872$, contained single mutations near one another and within the $126-\mathrm{kDa}$ protein and 183-kDa protein $5^{\prime}$ coterminal ORFs. These viruses induced systemic symptom phenotypes on $N$. tabacum cv. Xanthi that were identical to symptoms induced by $\mathrm{M}^{\mathrm{IC}} 1,3,6$ (data not shown).

By site-directed mutagenesis of $\mathrm{M}^{\mathrm{IC}}$ cDNA, it previously was shown that a single mutation of nucleotide 1,872 to the residue found in the TMV-U1 sequence yielded a virus, $\mathrm{M}^{\mathrm{IC}} 6$, which induces a severe systemic symptom phenotype (Shintaku et al. 1996) (Fig. 1, see sequence) and accumulates in systemic tissue (Derrick et al. 1997). Our current and previous results indicate that amino acids in or around residue 601 within the TMV 126-kDa protein are important for the systemic accumulation of TMV and disease induction in N. tabacum cv. Xanthi. The viruses described in this section were used in the following studies to determine the cause of their systemic accumulation phenotype.

\section{Host effect on vascular movement and systemic accumulation of $\mathrm{M}^{\mathrm{IC}} \mathbf{1 , 3}$.}

To fully understand the effect of the amino acid substitutions in $\mathrm{M}^{\mathrm{IC}} 1,3$ on vascular spread and accumulation, we searched for a host that allowed visible symptoms and measurable systemic accumulation of $\mathrm{M}^{\mathrm{IC}} 1,3 . N$. benthamiana was inoculated with virus and observed over time for systemic symptoms and virus accumulation. By 6 days postinoculation (dpi), N. benthamiana inoculated with $\mathrm{M}^{\mathrm{IC}} 1,3$ displayed chlorotic areas on systemic leaves, but these symptoms were much less severe (i.e., causing chlorosis in a lower percentage of leaf surface) than those induced by $\mathrm{M}^{\mathrm{IC}} 1,3,1864$ (data not shown). Extracts from systemic leaves of plants inoculated with $\mathrm{M}^{\mathrm{IC}} 1,3$ contained only $\mathrm{M}^{\mathrm{IC}} 1,3$ as determined by sequence analysis and by the lack of a disease phenotype induced by progeny on $N$. tabacum (data not shown). This indicated that the ability of $\mathrm{M}^{\mathrm{IC}} 1,3$ to systemically infect $N$. benthamiana was not due to further mutation.

Having identified a host that allowed measurable systemic accumulation of $\mathrm{M}^{\mathrm{IC}} 1,3$, grafting experiments were undertaken to determine if $\mathrm{M}^{\mathrm{IC}} 1,3$ could enter and spread through the vascular tissue of $N$. tabacum to the $N$. benthamiana scion, where it would be able to accumulate to measurable levels. Reciprocal grafts were made between $N$. tabacum and $N$. benthamiana

Table 1. Accumulation pattern of Tobacco mosaic virus variants in vascular cells of minor veins from inoculated leaves of Nicotiana tabacum

\begin{tabular}{lccccc}
\hline & \multicolumn{2}{c}{$\mathbf{M}^{\mathrm{IC}} \mathbf{1 , 3}$} & & \multicolumn{2}{c}{$\mathbf{M}^{\mathrm{IC}}$} \\
\cline { 2 - 3 } \cline { 5 - 6 } Cell type $^{\mathbf{a}}$ & $\mathbf{4 ~ d p i ~}^{\mathbf{b}}$ & $\mathbf{5} \mathbf{~ d p i}$ & & $\mathbf{4} \mathbf{d p i}$ & $\mathbf{5} \mathbf{~ d p i}$ \\
\hline $\mathrm{BS}^{\mathrm{c}}$ & $65 \%$ & $50 \%$ & & $40 \%$ & $91 \%$ \\
$\mathrm{VP}^{\mathrm{c}}$ & $50 \%$ & $50 \%$ & & $24 \%$ & $71 \%$ \\
$\mathrm{C}^{\mathrm{c}}$ & $0 \%$ & $0 \%$ & & $0 \%$ & $0 \%$ \\
Veins examined $^{\mathrm{d}}$ & $8(6)$ & $10(4)$ & & $18(6)$ & $7(4)$ \\
\hline
\end{tabular}

${ }^{\mathrm{a}} \mathrm{BS}=$ bundle sheath, $\mathrm{VP}=$ vascular parenchyma, and $\mathrm{C}=$ companion.

${ }^{\mathrm{b}}$ Days postinoculation $=\mathrm{dpi}$.

c Percent of total cells observed that were infected with virus by immunocytological analysis using antibody against the viral $\mathrm{CP}$.

${ }^{\mathrm{d}}$ Number in parenthesis indicate the number of sections examined from different leaves. and the leaves of the rootstocks were inoculated with $\mathrm{M}^{\mathrm{IC}} 1,3$, $\mathrm{M}^{\mathrm{IC}} 1,3,1864$, or $\mathrm{M}^{\mathrm{IC}}$. All three viruses accumulated in shoot apices of the $N$. benthamiana scions (Fig. 3). The time frame of virus accumulation in the young developing leaves of the scion ( $8 \mathrm{dpi}$ ) was indicative of phloem transport, and not cellto-cell spread, of the virus. In the reciprocal graft, $\mathrm{M}^{\mathrm{IC}} 1,3$ was more than 25-fold decreased in accumulation in the $N$. tabacum scion compared with $\mathrm{M}^{\mathrm{IC}}$ or $\mathrm{M}^{\mathrm{IC}} 1,3,1864$ (Fig. 3). These results indicated that $\mathrm{M}^{\mathrm{IC}} 1,3$ could move through vascular tissue in the restrictive host, $N$. tabacum, but either had difficulty exiting vascular tissue or establishing infection after exit. This conclusion was supported by the finding that $\mathrm{M}^{\mathrm{IC}} 1,3$ could be detected in only a few vein-associated cells near the shoot apex of intact $N$. tabacum by immunocytological analysis for viral CP (data not shown).

\section{Systemic symptoms induced by accumulation of TMV strains and mutants is positively correlated with a delay in transgene silencing.}

To determine whether RNA silencing had a role in limiting virus accumulation in systemic tissue of $N$. tabacum, N. tabacum cv. Xanthi plants expressing a 126-kDa protein:green fluorescent protein (GFP) fusion (126:GFP) were challenged with TMV strains and mutants, and the level of GFP expression in systemic leaves was monitored over time by confocal microscopy (Fig. 4A). The source of the 126-kDa protein ORF expressed in the transgenic plants was a cDNA clone of a TMV mutant, $\mathrm{M}^{\mathrm{IC}} 2$, previously characterized to induce severe systemic symptoms similar to $\mathrm{M}^{\mathrm{IC}} 6$ on $N$. tabacum $\mathrm{cv}$. Xanthi (Shintaku et al. 1996) (Fig. 1). M ${ }^{\mathrm{IC}} 2$ 126:GFP expression in systemic leaves was silenced earlier in plants inoculated with $\mathrm{M}^{\mathrm{IC}} 1,3$ than in those inoculated with $\mathrm{M}^{\mathrm{IC}}, \mathrm{M}^{\mathrm{IC}} 6$, or another mutant of $\mathrm{M}^{\mathrm{IC}}, \mathrm{M}^{\mathrm{IC}} 1-8$ (Fig. 4A, $7 \mathrm{dpi}$ and later). $\mathrm{M}^{\mathrm{IC}} 1-8$ induces TMV U1-like severe systemic symptoms on N. tabacum (Fig. 4A, 13 dpi) (Shintaku et al. 1996). The delay in silencing was positively correlated with the severity of symptoms induced by each virus (Fig 4A, 13 dpi).

To determine if the silencing phenotype was associated with the production of small RNAs, we analyzed tissue from leaves harvested at 13 dpi when silencing of GFP was apparent (Fig. 4B; extracts from leaves one node above those pictured in Fig. 4A). Small RNAs complementary to the virus sequence were present in all virus-challenged tissue. Additional experiments were conducted to determine if the level

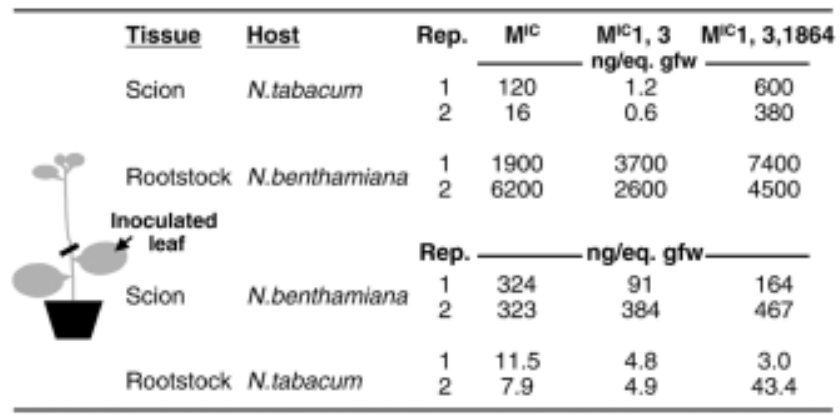

Fig. 3. Accumulation of Tobacco mosaic virus (TMV) strains or mutants in reciprocal grafts between two hosts differentially susceptible to visible systemic infection. Reciprocal grafts were made between Nicotiana tabacum cv. Xanthi and N. benthamiana rootstocks and scions. Accumulation of virus was determined at 8 days postinoculation by enzymelinked immunosorbent assay using antibody against the coat protein $(\mathrm{CP})$ of TMV. Inoculated mature leaves or shoot apices containing the youngest mature leaf and developing leaves were analyzed. Values represent amount of CP per equivalent gram of fresh weight (eq. gfw) across virus treatments from replicate (Rep.) plants from one experiment. The experiment was repeated twice. 
of the transgene transcript was down-regulated in tissue that had lost GFP fluorescence. By 18 dpi, transcript levels for the host transgene were very low in tissue exhibiting systemic silencing (Fig. 5). These results indicated that RNA silencing was targeted against both the viral RNA and the host transgene mRNA containing the viral sequence. We were unable to visualize small RNA representing the GFP-encoding portion of the transgene, possibly because this portion of the gene was not directly targeted by the silencing inducer; the viral RNA (data not shown).
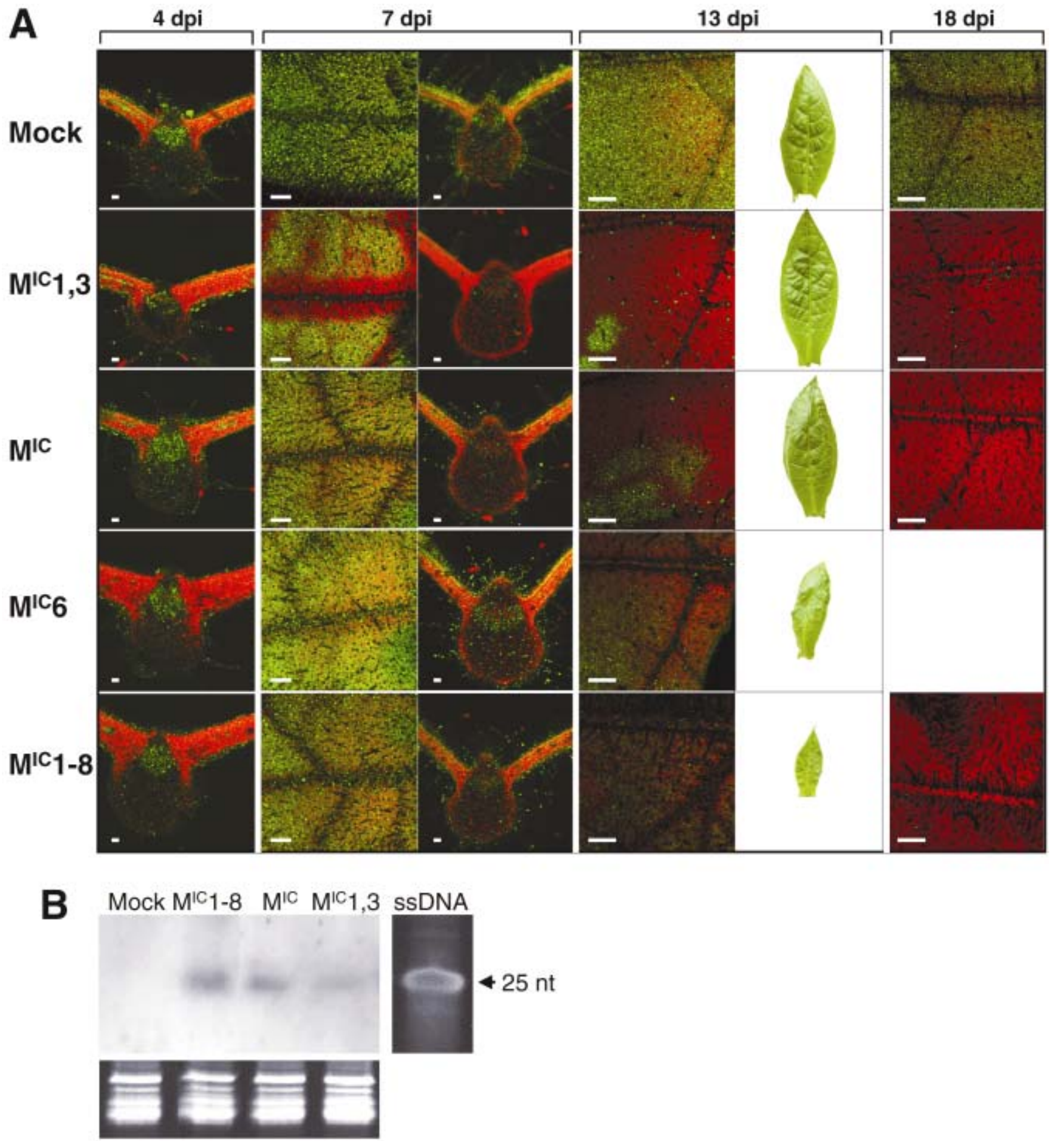

Fig. 4. Ability of Tobacco mosaic virus (TMV) strains or mutants expressing altered 126-kDa proteins to delay silencing of a 126-kDa protein:green fluorescent protein (GFP) fusion expressed in transgenic Nicotiana tabacum cv. Xanthi. Plants were inoculated with viruses $\left(\mathrm{M}^{\mathrm{IC}} 1,3, \mathrm{M}^{\mathrm{IC}}, \mathrm{M}^{\mathrm{IC}} 6\right.$, and $\mathrm{M}^{\mathrm{IC}} 1-$ 8, a virus displaying severe U1-like symptoms) or buffer (Mock). A, Images were taken of developmentally matched systemic leaves 7 to $10 \mathrm{~cm}$ in midrib length, at various days postinoculation (dpi). At 4 dpi, images are of transverse sections of midribs. At 7 dpi, the images at the left are of the leaf surface while the images at the right are of transverse sections of the midribs. At 13 and $18 \mathrm{dpi}$, the images are of the leaf surface or the whole leaf. Transverse and leaf surface images were obtained using a confocal system with $\mathrm{a} \times 10$ or $\times 2.5$ objective lens, respectively. Magnification bars equal $100 \mu \mathrm{m}$ and $1 \mathrm{~mm}$ for transverse sections and leaf surfaces, respectively. Whole-leaf images are of the leaves sampled for confocal analysis and were taken under natural light at equal focal distances. B, Accumulation of small RNAs in systemic tissue from plants inoculated with TMV strains or mutants $\left(\mathrm{M}^{\mathrm{IC}} 1-8, \mathrm{M}^{\mathrm{IC}}\right.$, and $\left.\mathrm{M}^{\mathrm{IC}} 1,3\right)$. Upper panel shows identification of small RNAs by Northern blot with probe specific to the 126-kDa protein open reading frame. Size marker ssDNA is a 25-mer oligonucleotide stained with ethidium bromide. Lower panel shows sample RNAs (200 to $500 \mathrm{bp}$ ) stained with ethidium bromide to indicate RNA quantities per lane. 
Suppression of RNA silencing of a nonviral transgene maps to the 126-kDa protein of TMV.

To determine if the 126- or 183-kDa proteins of TMV could suppress RNA silencing of a nonviral transgene, $N$. benthamiana expressing GFP localized to the endoplasmic reticulum (GFPer; line 16c plants) were used. These plants are silenced for GFPer expression by infiltrating young leaves with Agrobacterium tumefaciens expressing GFPer from a binary vector (Ruiz et al. 1998). Young systemic leaves fully silenced for GFPer expression were challenged with some of our TMV strains and mutants. $\mathrm{M}^{\mathrm{IC}} 1,3$ did not suppress silencing of GFPer in young systemically infected leaves, whereas $\mathrm{M}^{\mathrm{IC}} 1,3,6$ and $\mathrm{M}^{\mathrm{IC}} 6$ did suppress silencing of GFPer in these leaves (Fig. 6). Thus, suppression of GFPer silencing in N. benthamiana and delayed silencing of the $\mathrm{M}^{\mathrm{IC}} 2$ 126:GFP fusion in $N$. tabacum mapped to the same region within the 126- or 183kDa protein ORF of TMV (compare $\mathrm{M}^{\mathrm{IC}} 1,3$ and $\mathrm{M}^{\mathrm{IC}} 6$ in Fig. 4 with Fig. 6).

We determined the stability of the suppression by observing newly developing leaf tissue over time in the challenged $N$. benthamiana $16 \mathrm{c}$ plants. Virus that produced severe symptoms in $N$. benthamiana prevented continued plant growth and made it difficult to determine the stability of the suppression in these plants. However, $\mathrm{M}^{\mathrm{IC}} 1,3,6$, which produces milder systemic symptoms than U1 TMV, allowed continued plant growth. When plants infected with this virus were observed over time for GFPer expression and virus accumulation, it was determined that suppression of GFPer silencing was transient, occurring only within discrete sections of tissue at similar developmental stages within the plant, and was positively correlated with the presence of high levels of virus (green fluorescing leaf tissue, $5.96 \pm 2.45 \mu \mathrm{g}$ of virus per gram of fresh weight (gfw); distal red fluorescing leaf tissue, $0.76 \pm 0.09 \mu \mathrm{g}$ of virus/gfw; values represent means and standard errors of the mean for three replicates). This observation for GFP expression during $\mathrm{M}^{\mathrm{IC}} 1,3,6$ infection was different from what was observed during CMV infection, where suppression of GFP silencing was stronger (Fig. 6) and occurred over a wider range of tissue and for a longer period of time (data not shown).

The 126-kDa protein alone can suppress silencing of GFP.

To determine whether the $126-\mathrm{kDa}$ protein could suppress silencing in the absence of other viral proteins, constructs of $126-\mathrm{kDa}$ proteins from viruses that induce $\left(\mathrm{M}^{\mathrm{IC}} 2\right.$ ) (Shintaku et al. 1996) or fail to induce $\left(\mathrm{M}^{\mathrm{IC}} 1,3\right)$ systemic symptoms were fused with GFP and agroinfiltrated into $N$. benthamiana $16 \mathrm{c}$ plants expressing the GFPer. Because the GFP expressed in the fusion was not identical with the GFPer expressed in the $16 \mathrm{c}$ plants (78\% sequence identity between these GFPs), we also infiltrated $16 \mathrm{c}$ plants with free GFP to determine its ability to silence itself and the GFPer. Tissue infiltrated with Agrobacterium spp. containing the unfused GFP construct silenced both its own expression and the expression of GFPer by 5 days postinfiltration (dpinf) (Fig. 7A). In contrast, tissue infiltrated with $\mathrm{M}^{\mathrm{IC}} 2$ 126:GFP or $\mathrm{M}^{\mathrm{IC}} 1,3$ 126:GFP first displayed greater fluorescence compared with the buffer-infiltrated tissue (Fig. 7A, 3 dpinf). By 5 dpinf, tissue infiltrated with $\mathrm{M}^{\mathrm{IC}} 2$ 126:GFP delayed silencing of GFP expression in transformed plants to a greater extent than was observed for tissue infiltrated with $\mathrm{M}^{\mathrm{IC}} 1,3$ 126:GFP, which delayed silencing only slightly better than when GFP alone was infiltrated (Fig. 7A). Through semiquantitative reverse-transcriptase polymerase chain reaction (RT-PCR) analyses, it was determined that both GFP and GFPer mRNAs were protected by expression of $\mathrm{M}^{\mathrm{IC}} 2$ 126:GFP (Fig. 7B). In tissue expressing the 126:GFP proteins, large green fluorescent cytoplasmic bodies formed (Fig. 7A, see arrows). To better visualize these fluorescent bodies, nontrans- formed $N$. benthamiana was infiltrated with the Agrobacterium spp. expressing GFP, $\mathrm{M}^{\mathrm{IC}} 2$ 126:GFP, or $\mathrm{M}^{\mathrm{IC}} 1,3$ 126:GFP. In the absence of background GFPer expression, the formation of the green fluorescent cytoplasmic bodies due to $126-\mathrm{kDa}$ protein expression was evident (Fig. 7C). When Agrobacterium cultures expressing unfused $\mathrm{M}^{\mathrm{IC}} 2126-\mathrm{kDa}$ protein or GFP were co-infiltrated into leaves of nontransformed $N$. benthamiana, the silencing of GFP expression was delayed compared with leaves infiltrated only with Agrobacterium spp. expressing GFP (Fig. 8).

\section{DISCUSSION}

Previously, it was determined that TMV contains a suppressor of RNA silencing, but the specific viral protein or proteins necessary for this function was not identified (Voinnet et al. 1998, 1999). Results from our laboratory identified the 126- or $183-\mathrm{kDa}$ proteins and not the encoding RNA as the responsible elements controlling systemic pathogenicity in $N$. tabacum; however, the relationship of this phenomenon with RNA silencing was not addressed (Bao et al. 1996). These viral proteins also function in virus accumulation and cell-tocell movement (Derrick et al. 1997; Hirashima and Watanabe 2001; Lewandowski and Dawson 2000). In this study, we show that the suppression of RNA silencing maps to the 126$\mathrm{kDa}$ protein ORF of TMV and that the 126-kDa protein itself delays silencing of GFP in $N$. benthamiana.

We also determined that the suppression phenotype positively correlated with increased symptoms displayed in systemic tissue of $N$. tabacum infected with the various TMV strains and mutants (Fig. 4 and data not shown) (Shintaku et al. 1996). The correlation between increased symptoms and the ability to suppress silencing is known for multiple viral proteins, although being a suppressor does not guarantee virulence (Lucy et al. 2000; Voinnet et al. 2000). In our studies with $N$. benthamiana,

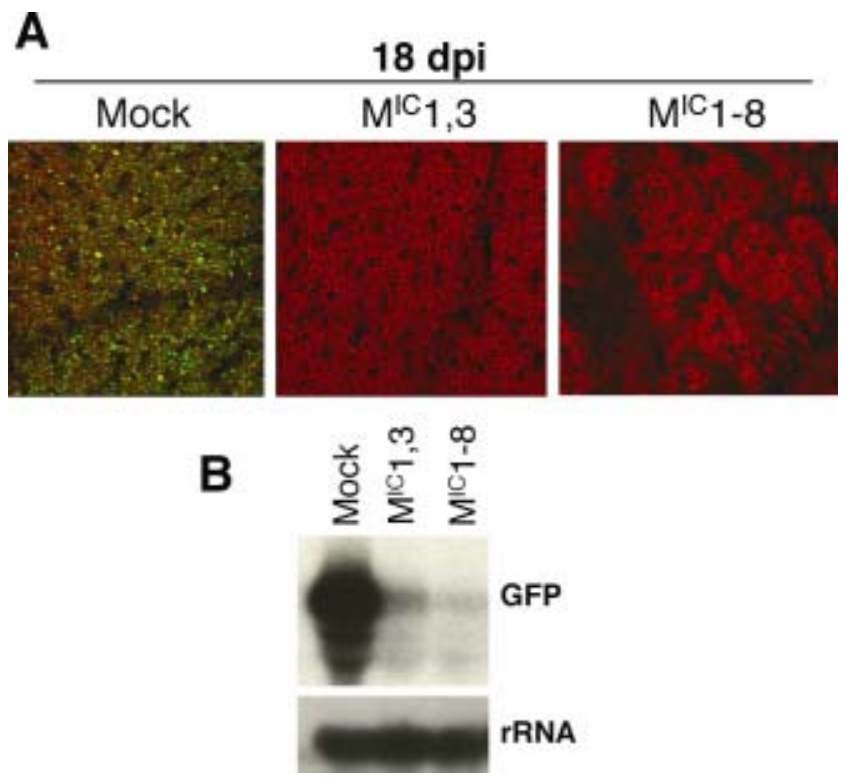

Fig. 5. Accumulation of transgene RNA in Nicotiana tabacum cv. Xanthi plants expressing the $126-\mathrm{kDa}$ protein:green fluorescent protein (GFP) fusion after inoculation with Tobacco mosaic virus variants. A, Confocal images from leaves at 18 days postinoculation (dpi) with virus $\left(\mathrm{M}^{\mathrm{IC}} 1,3\right.$, $\mathrm{M}^{\mathrm{IC}} 1-8$ ) or buffer (Mock). Leaf surface images were obtained using a confocal system with a $\times 2.5$ objective. $\mathbf{B}$, Results of northern analysis to determine GFP and rRNA transcript levels in imaged tissues shown in A. The blot was probed with a labeled fragment complementary to the GFP open reading frame (GFP), stripped, and then probed with a labeled fragment complementary to $18 \mathrm{~S}$ ribosomal RNA (rRNA). 
there also was general agreement between the severity of symptoms induced by the TMV strains and mutants and their suppressor activity (Results section and data not shown); however, for $\mathrm{M}^{\mathrm{IC}} 1,3$, its mild virulence on this host did not allow observable suppression of GFPer silencing (Fig. 7). Thus, maintaining some virulence did not guarantee observable suppressor activity by TMV. It is possible that visualizing suppression of silencing in $N$. benthamiana requires a higher level of $126-\mathrm{kDa}$ protein than is produced during $\mathrm{M}^{\mathrm{IC}} 1,3$ infection. The identification of the $126-\mathrm{kDa}$ protein as a suppressor of RNA silencing raises other interesting questions about the mechanism of suppression by this protein and the relationship of this mechanism to those utilized by other viral suppressors of RNA silencing.
For potyviruses, a correlation between virus accumulation and the suppression of GFP silencing was noted (Brignetti et al. 1998). In addition, Tobacco etch virus accumulates poorly in systemic tissue when the HC-Pro suppressor sequence was altered (Kasschau et al. 1997). Both of these observations are similar to what we observed for our TMV strains and mutants (Results section and Fig. 3). However, results from previous work studying the synergy between TMV and PVY suggest that the 126-kDa protein and HC-Pro function differently. Coinfection of TMV with PVY in a host resistant to PVY increases the accumulation of PVY from barely detectable to low levels (Valkonen 1992), and P1/HC-Pro increases TMV accumulation in leaves (Pruss et al. 1997). Synergy would not

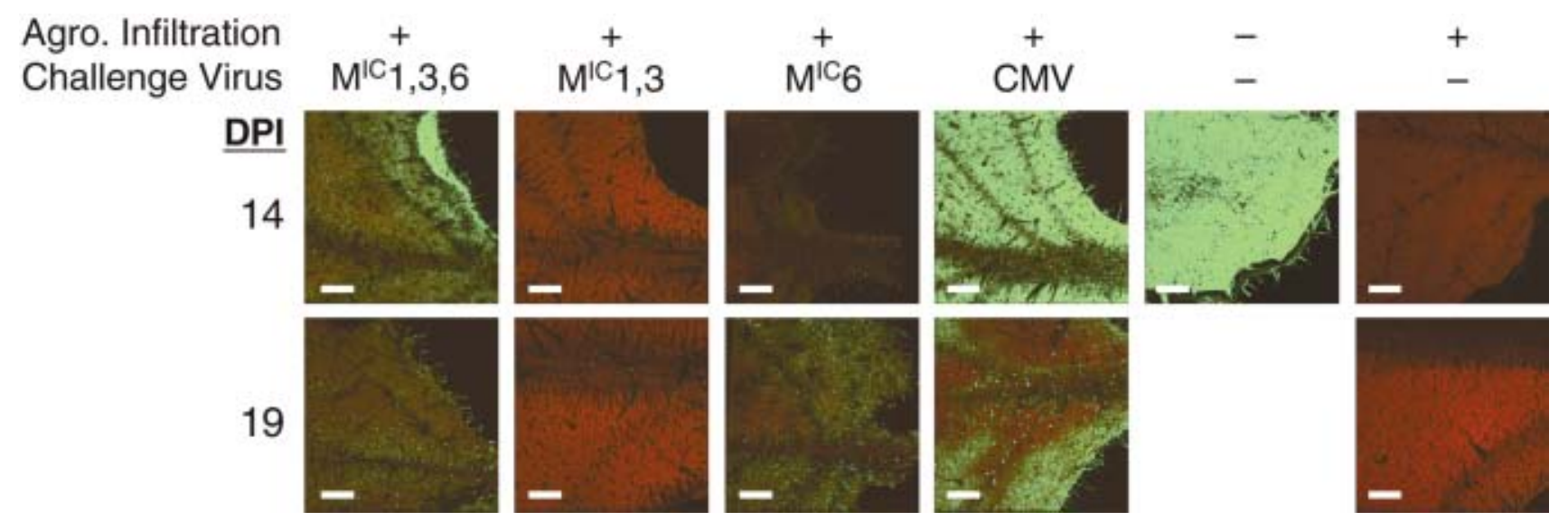

Fig. 6. Suppressed silencing of endoplasmic reticulum-localized green fluorescent protein localized to the endoplasmic reticulum (GFPer) in transgenic Nicotiana benthamiana by Tobacco mosaic virus (TMV) mutants altered in the 126-kDa protein. An Agrobacterium sp. expressing GFPer was infiltrated into young leaves of plants expressing GFPer (line 16c) to silence these plants (Agro. Infiltration). After young developing leaves displayed complete silencing of the transgene, fully silenced leaves were challenged with the TMV mutants $\left(\mathrm{M}^{\mathrm{IC}} 1,3,6, \mathrm{M}^{\mathrm{IC}} 1,3, \mathrm{M}^{\mathrm{IC}} 1,6\right)$, Cucumber mosaic virus $(\mathrm{CMV})$, or no virus. Young, developing noninfiltrated leaves were imaged under the confocal microscope for GFPer expression over time. DPI $=$ days postinoculation. Magnification bars equal $1 \mathrm{~mm}$.

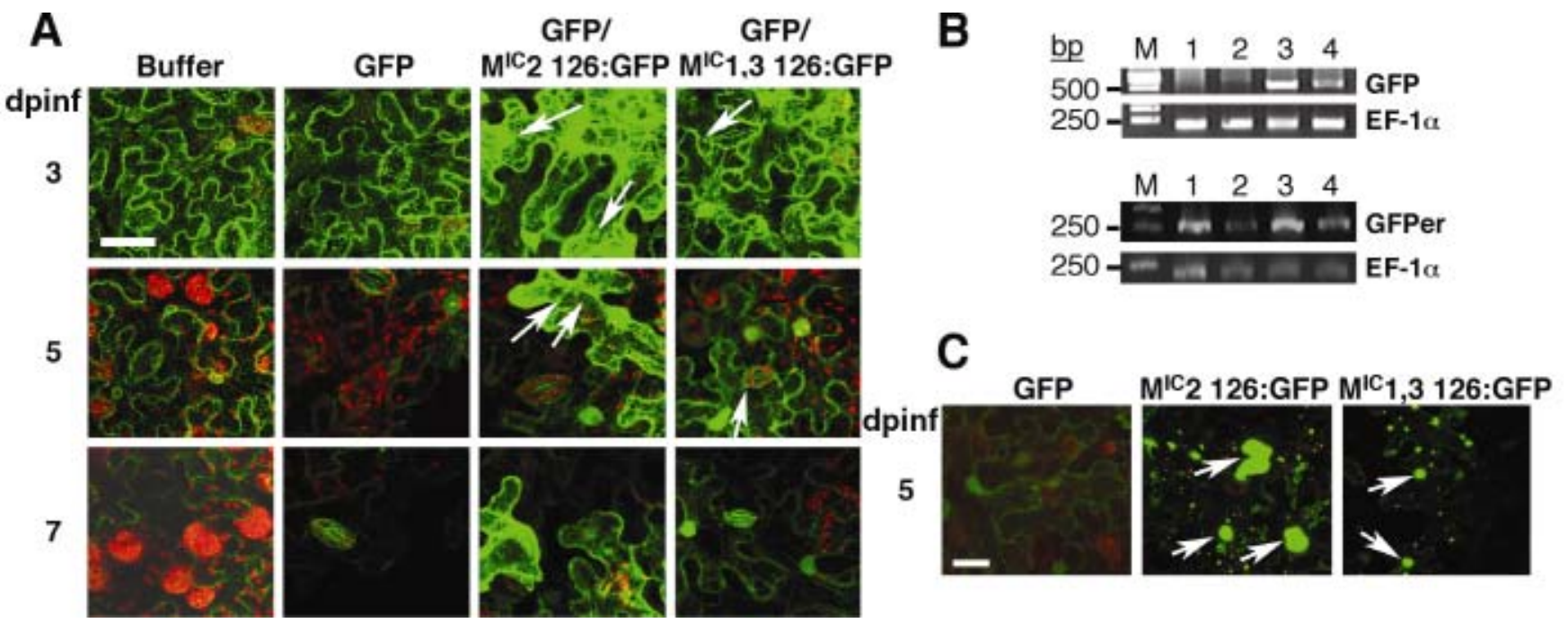

Fig. 7. Suppressed silencing of green fluorescent protein (GFP) and endoplasmic reticulum-localized GFP (GFPer) (protein and mRNA) by 126-kDa protein:GFP fusions in agroinfiltrated leaves of Nicotiana benthamiana expressing (line 16c) or not expressing GFPer. A and B, Leaves expressing GFPer were infiltrated with buffer, Agrobacterium tumefaciens expressing a GFP (GFP) with 78\% identity to GFPer, or a mixture of this Agrobacterium sp. with one expressing either the $\mathrm{M}^{\mathrm{IC}} 2126$-kDa protein:GFP fusion or $\mathrm{M}^{\mathrm{IC}} 1,3126-\mathrm{kDa}$ protein:GFP fusion. A, Leaves were imaged at various days postinfiltration (dpinf) using a confocal system and a $\times 63$ objective lens. Cells infiltrated with GFP that continued fluorescencing at 7 dpinf were stomatal cells that do not receive the silencing signal due to lack of plasmodesmal connections with other cells. Arrows point to cytoplasmic bodies formed during 126:GFP expression. Bar equals $50 \mu \mathrm{m}$ and all images were taken at the same focal distance. B, Presence of GFP and GFPer mRNAs in infiltrated tissues at 5 dpinf. Semiquantitative reverse-transcriptase polymerase chain reaction analyses of GFP or GFPer mRNA levels relative to those of EF-1 $\alpha$ as an internal control. Lanes 1 to 4 represent buffer, GFP, GFP/M ${ }^{\mathrm{IC}} 2$ 126:GFP, and GFP/M ${ }^{\mathrm{IC}} 1,3$ 126:GFP treatments, respectively. Lane M represents size markers (sizes indicated to left of lane). C, Leaves from nontransgenic plants were infiltrated with A. tumefaciens cultures described above. Arrows point to green fluorescent cytoplasmic bodies formed during 126:GFP expression. Bar equals $50 \mu \mathrm{m}$ and all images are at same focal distance. 
be expected for TMV and potyviruses if the 126-kDa protein and HC-Pro functioned similarly as suppressors. Further work will be required to clarify roles of the $126-\mathrm{kDa}$ protein and HC-Pro function during RNA silencing.

For CMV, the suppressor $2 b$ protein inhibits the activity of the mobile signal for systemic silencing (Guo and Ding 2002). We observed strong and extensive suppression of silencing in systemic tissue over long periods of time after inoculation of 16c plants with CMV (Fig. 6 and data not shown). This may reflect the ability of the $2 b$ protein to prevent the signal from activating systemic silencing, as shown by Guo and Ding (2002). We observed suppression of silencing only within developing tissue actively accumulating TMV; thus, further work is necessary to define the relationship between $126-\mathrm{kDa}$ protein- and $2 \mathrm{~b}$ protein-mediated suppression of silencing.

A third well-characterized viral suppressor, the $25-\mathrm{kDa}$ protein from PVX, blocks the production of the silencing signal in GFP-expressing $N$. benthamiana plants (line 16c) infiltrated with Agrobacterium spp. (Voinnet et al. 2000). TMV variants that induced more severe symptoms than $\mathrm{M}^{\mathrm{IC}} 1,3$ were able to suppress the silencing of GFP in $N$. benthamiana 16c plants (Fig. 7) (Voinnet et al. 1999), unlike what was observed for PVX (Voinnet et al. 1999), suggesting that the 126- and 25$\mathrm{kDa}$ proteins function differently to suppress RNA silencing. Also, in previous work, coinoculation of TMV with PVX results in increased numbers of PVX lesions (Thomson 1961), and tomato plants infected with Tomato mosaic virus, a close relative of TMV, and PVX induce much more severe symptoms than those observed after inoculation with either virus separately (Hull 2001). As with the potyviruses, synergy would not be expected if the 126-kDa protein functioned identically to the $25-\mathrm{kDa}$ protein from PVX in suppressing gene silencing.

The transient suppression of GFP silencing in $N$. benthamiana induced by $\mathrm{M}^{\mathrm{IC}} 1,3,6$ (Results section) suggests that viral RNA is protected from silencing pathway enzymes rather than inhibiting them. Previously, it was suggested that TMV, TBSV, and Cowpea mosaic virus may evade RNA silencing (Voinnet et al. 1999), and that aberrant RNAs from Tobacco rattle virus are not available to the silencing pathway (Dalmay et al. 2001). Recently, the apparent homologue of the 126-kDa protein in BMV, the 1a protein, was shown to line the interior of membrane-bound vesicles (spherules) in yeast (Schwartz et al. 2002). These spherules protect viral RNA from degradation by ribonucleases and it was suggested that this system could function to avoid host ribonucleases involved in RNA silencing. Our results can be interpreted within this theory. First, we observed cytoplasmic bodies expressing high levels of green fluorescence in leaves agroinfiltrated with $\mathrm{M}^{\mathrm{IC}} 2$ 126:GFP (Fig. $7 \mathrm{~A}$ and $\mathrm{C})$. The sizes of the bodies were correlated with the suppressor activity of the 126-kDa protein being expressed, suggesting a relationship between body formation and suppressor function (Fig. 7C) (J. Liu and R. S. Nelson, in preparation). Second, we and others have observed cytoplasmic bodies containing the 126-kDa protein during TMV infections (Heinlein et al. 1998; Szécsi et al. 1999). This indicates that body formation in the presence of the $126-\mathrm{kDa}$ protein occurs both during and in the absence of virus infection. Third, the apparent reversal of gene silencing in $N$. benthamiana leaves developing at or after the time of inoculation (Fig. 6 and discussed above) may have occurred because RNA silencing is not effective in the shoot meristem of silenced plants during TMV infection (Voinnet et al. 1998), and TMV in our studies arrived in an area of the shoot apex where silencing was not initiated. In this situation, the production of spherules or some other protective complex could protect viral and host RNA from degradation and allow extended, but transient, protein ex- pression. Although these results suggest relationships among 1a-mediated spherule formation in yeast, $126-\mathrm{kDa}$ protein-mediated cytoplasmic body formation, and RNA silencing, additional proof is required.

The protection of GFP mRNA by the $\mathrm{M}^{\mathrm{IC}} 2$ 126:GFP protein fusion (Fig. 7B) is an interesting result with respect to other research published on the ability of the $126-\mathrm{kDa}$ protein or its homologues to interact with RNA. The $126-\mathrm{kDa}$ protein is known to enhance the synthesis of its own RNA (Lewandowski and Dawson 2000). The enhanced accumulation of the viral RNA was suggested to be due to the binding of the $126-\mathrm{kDa}$ protein to the tRNA-like structure at the $3^{\prime}$ end of the positive sense viral RNA. Recently, this suggestion was proven true when a region of the $126-\mathrm{kDa}$ protein from TMV strain $\mathrm{L}$ encompassing the position-3 mutation within our TMV sequence was shown to be necessary for binding the tRNA-like structure in vitro (Osman and Buck 2003). For BMV, only RNA containing tRNA-like structures was stabilized by the 1a protein (Janda and Ahlquist 1998). Our studies indicate that the protection afforded by the $126-\mathrm{kDa}$ protein to the GFP-expressing RNAs does not require tRNA-like structures because these RNAs contain only a polyA tail. Whether the $126-\mathrm{kDa}$ protein is protecting only existing RNA or also aiding the production of the RNA, the translation of the RNA or the protection of the synthesized protein requires further study.

In summary, we have identified the $126-\mathrm{kDa}$ protein of TMV as a suppressor of RNA silencing. The suppression of silencing was transient and was correlated with the pathogenic strength of the virus, although virulence did not guarantee sup-

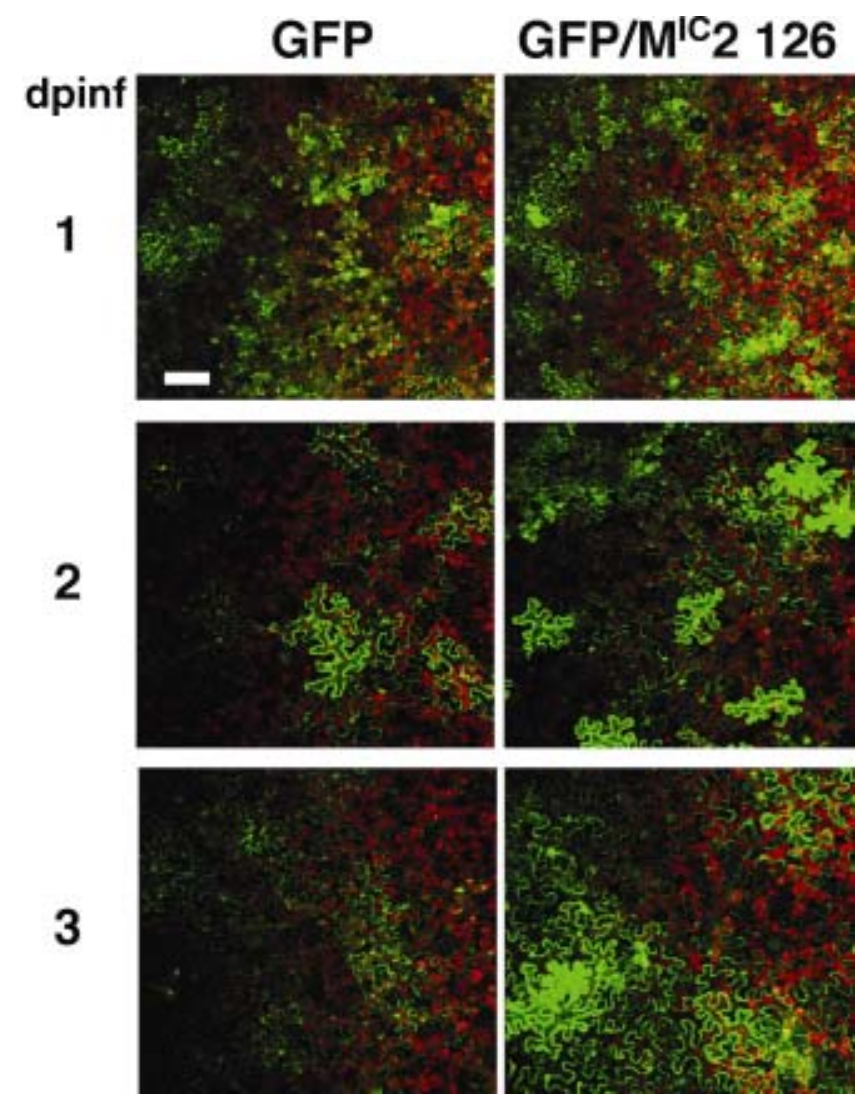

Fig. 8. Suppressed silencing of green fluorescent protein (GFP) by $\mathrm{M}^{\mathrm{IC}} 2$ 126-kDa protein in nontransformed Nicotiana benthamiana. Agrobacterium spp. directing expression of GFP (GFP) or GFP and $\mathrm{M}^{\mathrm{IC}} 2126-\mathrm{kDa}$ protein $\left(\mathrm{GFP} / \mathrm{M}^{\mathrm{IC}} 2126\right)$ were infiltrated into leaves. Infiltrated portions of leaves were imaged at various days postinfiltration (dpinf) using a confocal system and a $\times 10$ objective lens. Bar equals $200 \mu \mathrm{m}$ and all images were taken at same focal distance. 
pression. Increased pathogenicity was host specific. Mechanistically, the $126-\mathrm{kDa}$ protein may function to protect viral transcripts from enzymes of the RNA silencing pathway rather than defeat those enzymes.

\section{MATERIALS AND METHODS}

Virus strains and mutants, plants, and antibodies.

The M and U1 strains of TMV were obtained from previously described sources (Holt et al. 1990). $\mathrm{M}^{\mathrm{IC}}$ refers to the progeny of infectious transcript produced from a cDNA clone of the $\mathrm{M}$ strain (Holt et al. 1990). $\mathrm{M}^{\mathrm{IC}} 1,3, \mathrm{M}^{\mathrm{IC}} 1-8, \mathrm{M}^{\mathrm{IC}} 6$, and $\mathrm{M}^{\mathrm{IC}} 1,3,6$ were previously produced as described (Shintaku et al. 1996). CMV strain Fny was obtained from Dr. Marilyn Roossinck (Samuel Roberts Noble Foundation, Inc. Ardmore, OK, U.S.A.). N. tabacum cv. Xanthi, N. tabacum cv. Xanthi NN (hypersensitive host), and $N$. benthamiana were used. $N$. benthamiana line $16 \mathrm{c}$ transformed to express endoplasmic reticulum-directed GFP through $35 \mathrm{~S}$ promoter activity was obtained from Dr. David Baulcombe (Sainsbury Laboratories, Norwich, U.K.) and is described elsewhere (Brigneti et al. 1998; Ruiz et al. 1998). N. tabacum cv. Xanthi, transformed to express a fusion of the $\mathrm{M}^{\mathrm{IC}} 2$ (Shintaku et al. 1996) 126-kDa protein with the enhanced GFP through an enhanced 35S promoter activity, is described below.

Sources and purities of antibodies against the MP and the CP were as described (Derrick et al. 1997). Source and purity of antibody against the $126-\mathrm{kDa}$ protein and, due to read-through, the 183-kDa protein were as described (Nelson et al. 1993).

\section{Growth of N. tabacum and N. benthamiana and inoculation with virus.}

$N$. tabacum cv. Xanthi or Xanthi NN and N. benthamiana were germinated and grown as described for N. tabacum (Ding et al. 1995b). Cuttings of N. tabacum cv. Xanthi transformed to express the 126-kDa protein:GFP fusion were grown as described (Ding et al. 1995b). Virus strains and mutants were inoculated using equivalent infectivities as determined through bioassay, as described (Nelson et al. 1993). In vitro transcripts of virus cDNAs were produced and inoculated as described (Shintaku et al. 1996). After virus inoculation, plants were either left in a greenhouse under previously described conditions (Nelson et al. 1993) or placed in a growth chamber under previously described conditions (Ding et al. 1995b).

\section{Immunblots and enzyme-linked immunosorbent assay.}

For immunoblots shown in Figure 2, plant tissue was extracted with buffer A (Osman and Buck 1996) and analyzed as described (Derrick et al. 1997). Antibody against the 126-kDa protein was used at a 1:10,000 dilution.

For enzyme-linked immunosorbent assay (ELISA) analyses, tissue was harvested at the particular developmental stage and dpi as described in the results and the fresh weights recorded. Tissue was extracted and ELISAs conducted for CP accumulation as described for virus accumulation in transgenic tobacco expressing MP (Derrick et al. 1997).

\section{Isolation, purification, and sequencing of $\mathrm{M}^{\mathrm{IC}} 1,3$ mutants.}

Systemically-infected leaves were harvested, total RNA was isolated, and progeny virus was sequenced as described (Shintaku et al. 1996).

\section{Grafting studies.}

$N$. tabacum cv. Xanthi and $N$. benthamiana plants were grown as described (Ding et al. 1995b). At approximately 14 days after planting, reciprocal grafts were made between species using a wedge graft procedure (Kasschau et al. 1997). The grafted rootstock and scion were covered with a clear plastic lid to reduce transpiration demand on the recovering plants. After recovery and removal of the plastic lid, all leaves on the scion, except those less than $2 \mathrm{~cm}$ in midrib length, were removed to eliminate extraneous sink tissue. The first leaf down from the graft union on the rootstock was challenged with virus 1 or 2 days after removal of the scion leaves. Virus infectivity was equalized previous to inoculation of the grafted plants by bioassay on a hypersensitive host (N. tabacum cv. Xanthi NN).

\section{Production of transgenic plants expressing the 126-kDa protein:GFP fusion.}

A cDNA fragment encoding the $126-\mathrm{kDa}$ protein of $\mathrm{M}^{\mathrm{IC}}$ TMV was amplified from plasmid L19 (Shintaku et al. 1996) using Pfu polymerase (Stratagene, La Jolla, CA, U.S.A.) and a pair of primers, 5T (5'-CCATGCCATGGCGCTCGAGATG GCATACACACAGACA- $3^{\prime}$ ), where the underlined nucleotides indicate the TMV genome sequence from positions 69 to 86, and GT (5'-CCCTTGCTCACCATTTGTGTTCCTGCATCG$3^{\prime}$ ), where the underlined nucleotides indicate the sequence complementary to the TMV genome sequence from positions 3,401 to 3,416 . GFP was amplified from plasmid pEGFP (Clontech Laboratories, Inc., Palo Alto, CA, U.S.A.) using Pfu polymerase and a pair of primers, TG (5'-ATGCAGGAACAC AAATGGTGAGCAAGGGCG-3') and 3GFP (5'-CCATGCCA TGGCTCGAGTTACTTGTACAGCTCGT-3'). Amplified fragments were gel-purified and mixed as template for the fusion PCR with primers 5T and 3GFP, as described (Higuchi 1990). The PCR product was a fusion of the $126-\mathrm{kDa}$ protein gene and the GFP gene, which then was purified and digested with NcoI. The digested fragment was purified and ligated with plasmid pRTL2 (Restrepo et al. 1990) previously digested with NcoI. The ligation product was transformed into Escherichia coli HB101. The clone containing the insert with the correct orientation and sequence was named p126:GFP. A fragment from the cDNA clone of $\mathrm{M}^{\mathrm{IC}} 2$ (Bao et al. 1996) was digested with $M l u \mathrm{I}$ and DraIII sequentially, and the fragment ligated into p126:GFP previously digested with MluI and DraIII. This clone, referred to as p126-2:GFP, was partially digested with HindIII and the promoter-gene-terminator fragment was ligated into the binary vector, pGA482, previously digested with HindIII, to form pGA126-2:GFP $\left(\mathrm{M}^{\mathrm{IC}} 2\right.$ 126:GFP). A. tumefaciens (LBA 4404) then was transformed with this binary vector using standard protocols. Leaf discs from $N$. tabacum cv. Xanthi were transformed using A. tumefaciens containing $\mathrm{M}^{\mathrm{IC}} 2$ 126:GFP through standard protocols (Horsch et al. 1988). A line putatively containing $\mathrm{M}^{\mathrm{IC}} 2$ 126:GFP (line 1-1) was screened for the presence of the insert and expression of the transgene at the RNA and protein level. The line contained multiple inserts and, because this made the identification of a homozygous line difficult, was used as a source for cuttings for all challenge experiments with virus. The cuttings were developmentally matched by their plastochron indices to reduce plant-to-plant variability between treatments (Nelson et al. 1993).

\section{Confocal microscopy.}

GFP expression after virus challenge was monitored using a confocal microscope at described settings (Cheng et al. 2000).

\section{Small RNA detection.}

Small RNAs were detected as described (Itaya et al. 2001).

\section{Northern analysis.}

The tenth leaf above the inoculated leaf was harvested from transgenic $N$. tabacum expressing the 126-kDa protein:GFP 
fusion at $18 \mathrm{dpi}$ with virus or inoculum buffer alone. Each leaf was imaged under a confocal microscope and then the tissue extracted for total RNA using the RNeasy Plant Kit as directed (Qiagen, Valencia, CA, U.S.A.). Northern blot analysis was performed following standard protocols (Sambrook et al. 1989). In brief, total RNA (50 $\mu \mathrm{g} /$ lane) was loaded and separated on a $1.0 \%$ agarose/formaldehyde gel. The RNA was transferred to a nylon membrane (Amersham, Little Chalfont, U.K.) and the membrane was hybridized overnight at $42^{\circ} \mathrm{C}$ in $2 \times \mathrm{SSC}(1 \times \mathrm{SSC}$ is $0.15 \mathrm{M} \mathrm{NaCl}$ plus $0.015 \mathrm{M}$ sodium citrate) and $50 \%$ formamide with a ${ }^{32} \mathrm{P}$-labeled EGFP gene fragment (Clontech) produced by PCR amplification . The blot then was washed twice in $2 \times \mathrm{SSC}$ and $0.1 \%$ sodium dodecyl sulfate (SDS) and twice in $0.1 \times$ SSC and $0.1 \%$ SDS, both at $55^{\circ} \mathrm{C}$. The blot then was exposed to X-ray film for 1 week at $-80^{\circ} \mathrm{C}$.

\section{Agrobacterium spp. infiltration.}

pGA482 containing a GFP sequence (EGFP; Clontech) between enhanced $35 \mathrm{~S}$ promoter and $35 \mathrm{~S}$ terminator sequences from the plasmid pRTL2 was used (Itaya et al. 1997). The binary vector containing the GFP construct was transformed into A. tumefaciens strain LBA 4404 using standard protocols. To produce the $\mathrm{M}^{\mathrm{IC}} 1,3126-\mathrm{kDa}$ protein:GFP fusion, $\mathrm{p} 126-2$ :GFP was digested with $A f l I I$ and NheI and this fragment replaced with the corresponding fragment from the cDNA clone of $\mathrm{M}^{\mathrm{IC}} 1,3$ (Shintaku et al. 1996). The resulting plasmid was designated p126-1,3:GFP. Using the same procedures as described for the construction and expression of $\mathrm{M}^{\mathrm{IC}} 2$ 126:GFP, the promoter-gene-terminator fragment of p126-1,3:GFP was isolated and ligated into pGA482 to form $\mathrm{M}^{\mathrm{IC}} 1,3126: \mathrm{GFP}$, and this plasmid was used to transform an Agrobacterium sp. (strain LBA 4404). To produce $\mathrm{M}^{\mathrm{IC}} 2$ 126, the nucleotide sequence encoding the $126-\mathrm{kDa}$ protein from our $\mathrm{M}^{\mathrm{IC}} 2 \mathrm{cDNA}$ clone (Shintaku et al. 1996) was amplified using $P f u$ polymerase and a pair of primers, 5' 126-NcoI (5' AAACCATGG CATACACACAGACAGCTAC 3') and 3' 126-KpnI (5' AAA GGTACCCTATTGTGTTCCTGCATCGAC $3^{\prime}$ ). The underlined sequences represent $\mathrm{NcoI}$ and $K p n \mathrm{I}$ restriction sites. The amplified fragment was gel purified, digested with NcoI and $K p n I$, and cloned into pRTL2 digested with the same enzymes. The resulting plasmid was designated pRTL2 $\mathrm{M}^{\mathrm{IC}} 2$ 126. Using the same procedures as described for the construction and expression of $\mathrm{M}^{\mathrm{IC}} 2$ 126:GFP, the promoter-gene-terminator fragment of pRTL2 $\mathrm{M}^{\mathrm{IC}} 2126$ was isolated and ligated into pGA482 to form $\mathrm{M}^{\mathrm{IC}} 2126$, and this plasmid was used to transform an Agrobacterium sp. (strain LBA 4404).

LBA4404 containing a binary vector with the GFP, $\mathrm{M}^{\mathrm{IC}} 2$ 126:GFP, $\mathrm{M}^{\mathrm{IC}} 1,3$ 126:GFP, or $\mathrm{M}^{\mathrm{IC}} 2126$ sequence was grown under selection, diluted to an optical density (OD) $(600 \mathrm{~nm})$ of 1.0 , and then infiltrated after equally mixing cultures containing the GFP and one of the fusion constructs or GFP and buffer into the adaxial side of mature leaves of $N$. benthamiana (line 16c or nontransformed) as described (English et al. 1997; Voinnet et al. 1998). The final Agrobacterium dilution was to 0.5 OD for each binary vector infiltrated.

\section{Semiquantitative RT-PCR.}

RNA was extracted from Agrobacterium-infiltrated leaf tissue ( 4 by $4 \mathrm{~mm}$ ) using TRIzol as directed (Invitrogen, Carlsbad, CA, U.S.A.). Pellets were resuspended in $20 \mu \mathrm{l}$ of water. Primers specific for GFP (EGFP; Clontech), GFPer (GFP present in 16c plants), and EF-1 $\alpha$, as an internal control, were used to amplify sequences. Primer sequences were for i) GFP, $5^{\prime}$ CTCGTTGGGGTCTTTGCTC $3^{\prime}$ for RT and PCR and 5' CC ACAAGTTCAGCGTGTCC 3' for PCR; ii) GFPer, 5' GCACA AATTTTCTGTCAGT $3^{\prime}$ for RT and PCR and 5' AAACTTG ACTTCAGCACGT 3' for PCR; and iii) EF-1 $\alpha, 5^{\prime}$ ACGCTTG
AGATCCTTAACCGCAACATTCTT $3^{\prime}$ for RT and PCR and 5' TGGTGTCCTCAAGCCTGGTATGGTTGT 3' for PCR. Conditions for first-strand synthesis and PCR were slightly modified from those described (Shintaku et al. 1996). cDNA reactions were conducted using $1 \mu \mathrm{g}$ of total RNA extract as template into reaction mix, and $3^{\prime}$ primers for GFP and EF- $1 \alpha$ or GFPer and EF-1 $\alpha$ were added to the mixture. An aliquot of first-strand product $(1 \mu \mathrm{l})$ was added to PCR reaction mixtures containing GFP-, GFPer-, or EF- $1 \alpha$-specific primer pairs to a final volume of $25 \mu \mathrm{l}$. Cycles were $94^{\circ} \mathrm{C}$ for $30 \mathrm{~s}, 58^{\circ} \mathrm{C}$ for 30 $\mathrm{s}$, and $72^{\circ} \mathrm{C}$ for $30 \mathrm{~s}$. Preliminary experiments were conducted to identify cycle numbers that yielded near-linearly increasing product levels. A cycle number within this range was identified and used for the final analyses.

\section{ACKNOWLEDGMENTS}

We thank C. Su and T. Pierson for valuable preliminary information; $\mathrm{O}$. Voinnet and D. Baulcombe for enlightening discussions with R. S. Nelson; G. May and M. Yassi for valuable comments on the manuscript; T. Wallace, K. Flowers, J. Galloway, and K. Spiering for maintenance of plants; C. Ly for figure preparations; and A. Raney for final manuscript preparation.

\section{NOTE ADDED IN PROOF}

While this manuscript was under review, a report was published showing that the 126-kDa protein of a related virus, Tomato mosaic virus, was a suppressor of gene silencing (Kubota K., Tsuda S., Tamai A., and Meshi T. 2003. Tomato mosaic virus replication protein suppresses virus-targeted posttranscriptional gene silencing. J. Virol. 77:1101611026).

\section{LITERATURE CITED}

Al-Kaff, N. S., Covey, S. N., Kreike, M. M., Page, A. M., Pinder, R., and Dale, P. J. 1998. Transcriptional and posttrancriptional plant gene silencing in response to a pathogen. Science 279:2113-2115.

Bao, Y., Carter, S. A., and Nelson, R. S. 1996. The 126- and 183-kilodalton proteins of tobacco mosaic virus, and not their common nucleotide sequence, control mosaic symptom formation in tobacco. J. Virol. 70:6378-6383.

Baulcombe, D. C. 1999. Fast forward genetics based on virus-induced gene silencing. Curr. Opin. Plant Biol. 2:109-113.

Bonneau, C., Brugidou, C., Chen, L., Beachy, R. N., and Fauquet, C. 1998. Expression of the rice yellow mosaic virus $\mathrm{P} 1$ protein in vitro and in vivo and its involvement in virus spread. Virology 244:79-86.

Brigneti, G., Voinnet, O., Li, W.-X., Ji, L.-H., Ding, S.-W., and Baulcombe, D. C. 1998. Viral pathogenicity determinants are suppressors of transgene silencing in Nicotiana benthamiana. EMBO (Eur. Mol. Biol. Organ.) J. 17:6739-6746.

Carrington, J. C., Kasschau, K. D., and Johansen, L. K. 2001. Activation and suppression of RNA silencing by plant viruses. Virology 281:1-5.

Cheng, N. H., Su, C. L., Carter, S. A., and Nelson, R. S. 2000. Vascular invasion routes and systemic accumulation patterns of tobacco mosaic virus in Nicotiana benthamiana. Plant J. 23:349-362.

Covey, S. N., Al-Kaff, N. S., Lángara, A., and Turner, D. S. 1997. Plants combat infection by gene silencing. Nature 385:781-782.

Cronin, S., Verchot, J., Haldeman-Cahill, R., Schaad, M. C., and Carrington, J. C. 1995. Long-distance movement factor: A transport function of the potyvirus helper component proteinase. Plant Cell 7:549-559.

Dalmay, T., Horsefield, R., Braunstein, T. H., and Baulcombe, D. C. 2001 SDE3 encodes an RNA helicase required for post-transcriptional gene silencing in Arabidopsis. EMBO (Eur. Mol. Biol. Organ.) J. 20:20692077.

De Jong, W., and Ahlquist, P. 1995. Host-specific alterations in viral RNA accumulation and infection spread in a brome mosaic virus isolate with an expanded host range. J. Virol. 69:1485-1492.

Deom, C. M., Quan, S., and He, X. Z. 1997. Replicase proteins as determinants of phloem-dependent long-distance movement of tobamoviruses in tobacco. Protoplasma 199:1-8.

Derrick, P. M., Carter, S. A., and Nelson, R. S. 1997. Mutation of the 126 / $183 \mathrm{kDa}$ proteins of tobacco mosaic tobamovirus: The relationship of phloem-dependent accumulation with viral protein accumulation. Mol. Plant-Microbe Interact. 10:589-596. 
Ding, S. W., Li, W. X., and Symons, R. H. 1995a. A novel naturally occurring hybrid gene encoded by a plant RNA virus facilitates long distance virus movement. EMBO (Eur. Mol. Biol. Organ.) J. 14:5762-5772.

Ding, X. S., Shintaku, M. H., Arnold, S. A., and Nelson, R. S. 1995b. Accumulation of mild and severe strains of tobacco mosaic virus in minor veins of tobacco. Mol. Plant-Microbe Interact. 8:32-40.

English, J., Davenport, G., Elmayan, T., Vaucheret, H., and Baulcombe, D. 1997. Requirement of sense transcription for homology-dependent virus resistance and trans-inactivation. Plant J. 12:597-603.

Guo, H. S., and Ding, S. W. 2002. A viral protein inhibits the long range signaling activity of the gene silencing signal. EMBO (Eur. Mol. Biol. Organ.) J. 21:398-407.

Hamilton, A. J., and Baulcombe, D. C. 1999. A species of small antisense RNA in posttranscriptional gene silencing in plants. Science 286:950952 .

Heinlein, M., Padgett, H. S., Gens, J. S., Pickard, B. G., Casper, S. J., Epel, B. L., and Beachy, R. N. 1998. Changing patterns of localization of the tobacco mosaic virus movement protein and replicase to the endoplasmic reticulum and microtubules during infection. Plant Cell 10:1107-1120.

Higuchi, R. 1990. Recombinant PCR. Pages 177-183 in: PCR Protocols: A Guide to Methods and Applications. M. A. Innis, D. H. Gelfand, J. J. Sninsky, and T. J. White, eds. Academic Press, Inc., San Diego, CA.

Hirashima, K., and Watanabe, Y. 2001. Tobamovirus replicase coding region is involved in cell-to-cell movement. J. Virol. 75:8831-8836.

Holmes, F. O. 1934. A masked strain of tobacco mosaic virus. Phytopathology 24:845-873.

Holt, C. A., Hodgson, R. A. J., Coker, F. A., Beachy, R. N., and Nelson, R. S. 1990. Characterization of the masked strain of tobacco mosaic virus: Identification of the region responsible for symptom attenuation by analysis of an infectious cDNA clone. Mol. Plant-Microbe Interact. 3:417-423.

Hong, Y., Saunders, K., and Stanley, J. 1997. Transactivation of Dianthin transgene expression by African cassava mosaic virus AC2. Virology 228:383-387.

Horsch, R. B., Fry, J. E., Hoffmann, N. L., Neidermeyer, J., Rogers, S. G. and Fraley, R. T. 1988. Pages A5:1-5 in: Plant Molecular Biology Manual. Kluwer Academic Publishers, Dordrecht, Belgium

Hull, R. 2001. Matthews' Plant Virology. Academic Press, San Diego, CA and London.

Itaya, A., Folimonov, A., Matsuda, Y., Nelson, R., and Ding, B. 2001. Potato spindle tuber viroid as initiator of gene silencing in infected tomato. Mol. Plant-Microbe Interact. 14:1332-1334.

Janda, M., and Ahlquist P. 1998. Brome mosaic virus RNA replication protein 1a dramatically increases in vivo stability but not translation of viral genomic RNA3. Proc. Natl. Acad. Sci. U.S.A. 95:2227-2232

Kasschau, K. D., Cronin, S., and Carrington, J. C. 1997. Genome amplification and long distance movement functions associated with the central domain of tobacco etch potyvirus helper component-proteinase. Virology 228:251-262.

Lakshman, D. K., and Gonsalves, D. 1985. Genetic analyses of two largelesion isolates of cucumber mosaic virus. Phytopathology 75:758-762.

Lewandowski, D. J., and Dawson, W. O. 2000. Functions of the 126- and 183-kDa proteins of tobacco mosaic virus. Virology 271:90-98.

Lindbo, J. A., Silva-Rosales, L., and Dougherty, W. G. 1993. Pathogen derived resistance to potyviruses: Working, but why? Semin. Virol. 4:369379

Lucy, A. P., Guo, H. S., Li, W. X., and Ding, S. W. 2000. Suppression of post-transcriptional gene silencing by a plant viral protein localized in the nucleus. EMBO (Eur. Mol. Biol. Organ.) J. 19:1672-1680.

Mlotshwa, S., Voinnet, O., Mette, M. F., Matzke, M., Vaucheret, H., Ding, S.-W., Pruss, G., and Vance, V. B. 2002. RNA silencing and the mobile silencing signal. Plant Cell S289-S301.

Nelson, R. S., Li, G., Hodgson, R. A. J., Beachy, R. N., and Shintaku, M. H. 1993. Impeded phloem-dependent accumulation of the masked strain of tobacco mosaic virus. Mol. Plant-Microbe Interact. 6:45-54.

Nelson, R. S., and van Bel, A. J. E. 1998. The mystery of virus trafficking into, through and out of the vascular tissue. Pages 476-533 in: Progress in Botany. U. Lüttge, ed. Springer-Verlag, Berlin.

Osman, T. A. M., and Buck, K. W. 1996. Complete replication in vitro of tobacco mosaic virus RNA by a template-dependent, membrane-bound
RNA polymerase. J. Virol. 70:6227-6234.

Osman, T. A. M., and Buck, K. W. 2003. Identification of a region of the tobacco mosaic virus 126- and 183-kilodalton replication proteins which binds specifically to the viral 3'-terminal tRNA-like structure. J. Virol. 77:8669-8675

Pruss, G., Ge, X., Shi, X. M., Carrington, J. C., and Vance, V. B. 1997. Plant viral synergism: The potyviral genome encodes a broad-range pathogenicity enhancer that transactivates replication of heterologous viruses. Plant Cell 9:859-868.

Ratcliff, F., Harrison, B. D., and Baulcombe, D. C. 1997. A similarity between viral defense and gene silencing in plants. Science 276:15581560

Restrepo, M. A., Freed, D. D., and Carrington, J. C. 1990. Nuclear transport of plant potyviral proteins. Plant Cell 2:987-998.

Roossinck, M. J., and Palukaitis, P. 1990. Rapid induction and severity of symptoms in zucchini squash (Cucurbita pepo) map to RNA 1 of cucumber mosaic virus. Mol. Plant-Microbe Interact. 3:188-192.

Ruiz, M. T., Voinnet, O., and Baulcombe, D. C. 1998. Initiation and maintenance of virus-induced gene silencing. Plant Cell 10:937-946.

Sambrook, J., Fritsch, E. F., and Maniatis, T. 1989. Molecular Cloning: A Laboratory Manual. Cold Spring Harbor Laboratory Press, Cold Spring Harbor, NY.

Scholthof, H. B., Scholthof, K.-B. G., Kikkert, M., and Jackson, A. O. 1995. Tomato bushy stunt virus spread is regulated by two nested genes that function in cell-to-cell movement and host-dependent systemic invasion. Virology 213:425-438.

Schwartz, M., Chen, J., Janda, M., Sullivan, M., den Boon, J., and Ahlquist, P. 2002. A positive-strand RNA virus replication complex parallels form and function of retrovirus capsids. Mol. Cell 9:505-514.

Shintaku, M. H., Carter, S. A., Bao, Y., and Nelson, R. S. 1996. Mapping nucleotides in the $126-\mathrm{kDa}$ protein gene that control the differential symptoms induced by two strains of tobacco mosaic virus. Virology 221:218-225.

Smith, H. A., Swaney, S. L., Parks, T. D., Wernsman, E. A., and Dougherty, W. G. 1994. Transgenic plant virus resistance mediated by untranslatable sense RNAs: Expression, regulation, and fate of nonessential RNAs. Plant Cell 6:1441-1453.

Szécsi, J., Ding, X. S., Lim, C. O., Bendahmane, M., Cho, M. J., Nelson, R. S., and Beachy, R. N. 1999. Development of tobacco mosaic virus infection sites in Nicotiana benthamiana. Mol. Plant-Microbe Interact. 12:143-152.

Thomson, A. D. 1961. Effect of tobacco mosaic virus and potato virus Y on infection by potato virus X. Virology 13:262-264.

Traynor, P., Young, B. M., and Ahlquist, P. 1991. Deletion analysis of brome mosaic virus 2 a protein: Effects on RNA replication and systemic spread. J. Virol. 65:2807-2815.

Valkonen, J. P. T. 1992. Accumulation of potato virus Y is enhanced in Solanum brevidens also infected with tobacco mosaic virus or potato spindle tuber viroid. Ann. Appl. Biol. 121:321-327.

Vance, V., and Vaucheret, H. 2001. RNA silencing in plants-defense and counterdefense. Science 292:2277-2280.

Voinnet, O. 2001. RNA silencing as a plant immune system against viruses. Trends Genet. 17:449-459.

Voinnet, O., Lederer, C., and Baulcombe, D. C. 2000. A viral movement protein prevents spread of the gene silencing signal in Nicotiana benthamiana. Cell 103:157-167.

Voinnet, O., Pinto, Y. M., and Baulcombe, D. C. 1999. Suppression of gene silencing: A general strategy used by diverse DNA and RNA viruses of plants. Proc. Natl. Acad. Sci. U.S.A. 96:14147-14152.

Voinnet, O., Vain, P., Angell, S., and Baulcombe, D. C. 1998. Systemic spread of sequence-specific transgene RNA degradation in plants is initiated by localized introduction of ectopic promoterless DNA. Cell 95:177-187.

Weiland, J. J., and Edwards, M. C. 1994. Evidence that the aa gene of barley stripe mosaic virus encodes determinants of pathogenicity to oat (Avena sativa). Virology 201:116-126.

Zamore, P. D. 2001. RNA interference: Listening to the sound of silence. Nat. Struct. Biol. 8:746-749.

Zamore, P. D., Tuschl, T., Sharp, P. A., and Bartel, D. P. 2000. RNAi: Double-stranded RNA directs the ATP-dependent cleavage of mRNA at 21 to 23 nucleotide intervals. Cell 101:25-33. 